\title{
References:
} $208 \mathrm{p}$.

1. Kolodiy AM Principles of Ukrainian law. K .: Юрінком Інтер, 1998,

2. Guyvan P.D. Statute of limitations. Monograph. Kharkiv : Pravo, 2012. 448 p.

3. Dobrovolsky AA Claim form of protection of rights. М. : Изд-во Моск. ун-та, 1965. 189 p.

4. Kirillova M.Ya. Statute of limitations. М. : Юридическая литература, $1966.156 \mathrm{p}$.

5. Frolov Yu., Frolova G. Some problems of application of limitation periods, their differences from other terms in civil law. Підприємництво, господарство і право. 2001. № 10. Рp. 45-47.

DOI https://doi.org/10.30525/978-9934-588-92-1-35

\section{УСНІ ПОЯСНЕННЯ УЧАСНИКІВ СПРАВИ ЯК ФОРМА ДОКАЗІВ В ЦИВІЛЬНОМУ СУДОЧИНСТВІ УКРАЇНИ}

\author{
Короєд С. О. \\ доктор юридичних наук, дочент, \\ професор кафедри права \\ Приватного вищого навчального закладу Університету Короля Данила \\ м. Івано-Франківськ, Украӥна
}

Цивільне судочинство $є$ найпоширенішою і пріоритетною формою судового захисту порушених прав, адже саме в системі загальних судів в порядку цивільного судочинства розглядаються і вирішуються справи за участю громадян, які $\epsilon$ безпосередніми учасниками цивільних, сімейних, трудових, земельних та інших правовідносин, а відтак лише їм добре відомі обставини існування підстав виникнення, зміни та припинення таких правовідносин, а також причини спорів, які при цьому виникають у зв'язку із діями самих сторін. Як справедливо зауважив М.К. Треушніков, сторони можуть помилятися, давати фактам свою інтерпретацію, по-своєму пояснювати факти. Але за будьяких умов сторони є носіями певної доказової інформації про факти, а їх пояснення $є$ доказами [1, с. 157]. Пояснення сторін можуть дати суду важливий матеріал для визначення предмету доказування, кола доказових фактів тощо [2, с. 207]. Це забезпечується завдяки усності 
цивільного судочинства, адже цивільні справи розглядаються в судах зазвичай усно.

Характеризуючи усність як принцип цивільного процесу, ще дореволюційний процесуаліст $Є$. . Васьковський виділяв такі іiі переваги: усне провадження дозволяє особисте спілкування суду зі сторонами, що $\epsilon$ так само важливим для з'ясування дійсних обставин справи, як й особистий допит свідків судом; при усному провадженні суд може сприйняти весь фактичний матеріал процесу повно і одразу; усна форма провадження більш зручна для сторін, адже більшість людей краще висловлює свої думки усно; усність провадження надає процесу рухомість, тобто можливе формальне керівництво процесом 3 боку суду; усна форма провадження необхідна для приведення в дію принципу публічності (відкритості слухання). При цьому, Є.В. Васьковський визнавав доцільною процесуальну систему за Статутом цивільного судочинства 1864 p., яка надавала однакове значення як усній, так й письмовій формі змагання сторін (статті 324, 339, 456 Статуту цивільного судочинства 1864 р.) [3, с. 117-122].

ЦПК України 1963 року теж виділяв таку процесуальну форму доказів (процесуальну форму одержання фактичних даних), як пояснення сторін і третіх осіб, їх представників (ст. 27 ЦПК 1963 р.), що було логічним з огляду на особистий характер таких пояснень $\mathrm{i}$ неможливість їх заміни іншими (письмовими) доказами зважаючи на відсутність письмового оформлення багатьох цивільних правовідносин (як договірних, так й позадоговірних). I навіть, якщо договірні відносини сторін в силу закону повинні мати письмову форму (що виключає можливість доказування на підставі показань свідків згідно зі ст. 218 ЦК України), то так чи інакше особисті пояснення учасників справи як безпосередніх учасників таких цивільних правовідносин будуть першоджерелом відомостей про взаємовідносини сторін. А в сімейних правовідносинах, коли, наприклад, предметом спору $\epsilon$ розірвання шлюбу чи участь у вихованні дитини, показання подружжя (батьків дитини) є чи не єдиним першоджерелом доказової інформації.

Водночас ЦПК України 2004 року позбавив пояснення сторін і третіх осіб статусу самостійного засобу доказування. Пояснення сторін, третіх осіб, їхніх представників стали визнаватися засобом доказування лише у випадку, якщо вони були допитані як свідки (ст. 57 ЦПК 2004 р.). Хоча водночас було регламентовано порядок надання пояснень особами, які беруть участь у справі (тобто, не в статусі свідка) під час розгляду справи по суті (ст. 176 ЦПК 2004 р.). Разом 3 тим, заслуховування пояснень осіб, які беруть участь у справі за ст. 176 ЦПК 2004 року не було пов'язано з необхідністю їх юридичної оцінки 
судом чи перевірки наявними в справі доказами. Так само не було встановлено співвідношення доказової сили усних пояснень осіб, наданих в судовому засіданні (чи наявних в справі письмових пояснень сторін), із викладеними в позовній заяві та письмових запереченнях проти позову доводами сторін. Хоча за результатами судового розгляду суд під час ухвалення рішення має встановити, чи мали місце обставини (факти), на які сторони посилались як на підставу своїх вимог і заперечень, та якими доказами вони підтверджуються.

Відповіді осіб, які беруть участь у справі на питання, які їм були задані іншими учасниками справи (право задавати запитання передбачено ст. 27 ЦПК 2004 р.), прямо відносились до пояснень осіб, які беруть участь у справі (ч. 5 ст. 176 ЦПК 2004 р.). А відтак, доказової сили юридично теж не мали, за винятком випадків, коли сторону було допитано як свідка.

Новий ЦПК України 2017 року (чинна на сьогодні редакція) взагалі не згадує в переліку засобів доказування такої процесуальної форми доказів, як пояснення учасників справи, допитаних в якості свідків (ст. 76 ЦПК 2017 р.). Хоча в іншій статті передбачає можливість допиту сторін, третіх осіб і ї представників як свідків (ст.ст. 92, 234 ЦПК 2017 р.), що надаватиме таким поясненням доказової сили як показання свідків, які є засобом доказування.

Водночас пояснення осіб, які беруть участь у справі по суті спору (ст. 176 ЦПК 2004 р.) було замінено вступним словом учасників справи (ст. 227 ЦПК 2017 р.) та запроваджено письмові заяви по суті справи, виключно в яких учасники справи викладають свої вимоги, заперечення, аргументи, пояснення та міркування щодо предмета спору. А такими заявами по суті спору є: позовна заява; відзив на позовну заяву (який по суті замінив письмові заперечення відповідача проти позову, які були передбачені ст. 128 ЦПК 2004 р.); відповідь на відзив; заперечення; пояснення третьої особи щодо позову або відзиву. Суд при цьому може дозволити учаснику справи подати додаткові пояснення щодо окремого питання, яке виникло при розгляді справи, якщо визнає це за необхідне (ст. 174 ЦПК 2017 р.).

Що стосується пояснень (аргументів, міркувань) щодо процесуальних питань, то такі пояснення викладаються у заявах та клопотаннях, а також запереченнях проти заяв і клопотань, які подаються в письмовій або усній формі (ч.ч. 1, 2 ст. 182 ЦПК 2017 р.).

Отже, за загальним правилом, всі «пояснення» учасників справи мають викладатись у заявах по суті справи (які завжди є письмовими). I лише пояснення щодо процесуальних питань можуть викладатись не тільки в письмових, а й усних заявах та клопотаннях. 
Проте в тексті ЦПК 2017 року неодноразово згадується про «пояснення учасників справи» в різних аспектах. При цьому зі змісту Кодексу випливає, що пояснення учасників справи необов'язково повинні викладатись в письмових заявах по суті спору. Такі пояснення можуть бути також особистими - наданими особисто (усно) в судовому засідання учасниками справи як за ініціативою суду, так й з власної ініціативи (зокрема, в процесі дослідження доказів чи після цього). Тим самим усні пояснення учасників справи доповнюють доказовий матеріал, а відтак займають своє самостійне місце в доказовій діяльності.

Доказову діяльність (судове доказування) визначають науковці як процесуальну діяльність сторін, інших учасників справи, що випливає із сутності принципу змагальності цивільного права, заснована на сукупності процесуальних прав і обов'язків та полягає у повідомленні суду про фактичні обставини справи, надання доказів, спростування доказів, заявлення клопотань про витребування доказів, участь в дослідженні і оцінці доказів, а також діяльність суду, що полягає в оцінці доказів, їх витребуванню за клопотанням сторін, пропозиції сторонам усунути прогалини в доказовому матеріалі, яка спрямована на з'ясування фактичних обставин справи, прав i обов'язків сторін, та ухвалення законного та обгрунтованого рішення цивільній справі [4, с. 171].

Отже, навіть 3 цього теоретичного визначення вбачається, що повідомлення суду про фактичні обставини справи $є$ доказовою діяльністю. А в таких повідомленнях може міститись інформація про визнання обставин справи, а це згідно з ч. 1 ст. 82 ЦПК як раз може зазначатись як в заявах по суті спору, так й усних поясненнях учасників справи та їхніх представників.

Цей висновок підтверджується й положеннями ч. 1 ст. 229 ЦПК, згідно $з$ якими суд під час розгляду справи повинен безпосередньо дослідити докази у справі: ознайомитися 3 письмовими та електронними доказами, висновками експертів, поясненнями учасників справи, викладеними в заявах по суті справи, показаннями свідків, оглянути речові докази.

Тобто, пояснення учасників справи, викладені в заявах по суті справи, прямо визнаються доказами, які суд повинен безпосередньо дослідити під час розгляду справи шляхом ознайомлення 3 ними. Вважаємо, що вказана норма так само стосується й особистих (усних) пояснень учасників справи, наданих у судовому засіданні.

Все викладене вище переконливо свідчить, що пояснення учасників справи (як усні, так й в письмових заявах по суті справи) мають доказове значення нарівні з іншими доказами, які суд має дослідити в сукупності. 


\title{
Література:
}

1. Треушников М. К. Судебные доказательства. М.: ОАО «Издательский дом «Городец», 2004. 272 с.

2. Гражданский процесс: Учебник / Под ред. В. А. Мусина, Н. А. Чечиной, Д. М. Чечота. М. : «Проспект», 1997. 480 с.

3. Васьковский Е. В. Учебник гражданского процесса. Под редакцией и с предисловием В. А. Томсинова. М. : Издательство «Зерцало», 2003. 464 с.

4. Проблемы науки гражданского процессуального права / В. В. Комаров, $\quad$ В. А. Бигун, В. В. Баранкова; Под ред. проф. В. В. Комарова. Харьков : Право, 2002. 440 с.

DOI https://doi.org/10.30525/978-9934-588-92-1-36

\section{ДО ПИТАННЯ ЩОДО ПРОБЛЕМ УДОСКОНАЛЕННЯ ЦИВІЛЬНОГО ЗАКОНОДАВСТВА НА СУЧАСНОМУ ЕТАПІ}

\author{
Куриліна В. В. \\ студентка магістратури другого року навчання \\ Інституту права
}

Київського національного університету імені Тараса Шевченка

м. Київ, Украӥна

Важко заперечувати, що постійне вдосконалення законодавства $€$ одним із найвагоміших засобів забезпечення ефективності функціонування правової системи держави. Зважаючи на це, цивілістична наука України має своїм основним завданням проведення досліджень, спрямованих на вдосконалення чинного цивільного законодавства [1, с. 53].

На сьогодні можна констатувати наявність низки проблем цивільного законодавства, серед яких:

- неузгодженість понятійного апарату, термінологічні неточності, відсутність нормативно закріплених визначень понять чи різне їх трактування у різних актах цивільного законодавства;

- недостатність чи відсутність законодавчої регламентації окремих видів суспільних відносин;

- відсутність легальної чіткої ієрархії законів, концептуальна неузгодженість нових юридичних норм із прийнятими раніше, колізії між актами цивільного законодавства та ін. [2, с. 61]. 